\title{
Iranian Bazaars and the Social Sustainability of Modern Commercial Spaces in Iranian Cities
}

\author{
"Kimia Ghasemi, Mostafa Behzadfar and Mahdi Hamzenejad
}

\begin{abstract}
First submission: 4 March 2020; Accepted: 30 June 2020; Published: 30 July 2021
To cite this article: Kimia Ghasemi, Mostafa Behzadfar and Mahdi Hamzenejad (2021). Iranian bazaars and the social sustainability of modern commercial spaces in Iranian cities. Journal of Construction in Developing Countries, 26(1): 1-18. https://doi.org/10.21315/jcdc2021.26.1.1.
\end{abstract}

To link to this article: https://doi.org/10.21315/jcdc2021.26.1.1

\begin{abstract}
According to some factors such as participation, interactions, identification and security, Iran's traditional bazaars are good examples of social sustainability. In fact, bazaars are not considered as merely an economic environment but also an environment for many social activities due to their status and their location in the important environments and centres of the city, and the significant role and social status of market's businessmen in the city. However, in the modern industrial era and with appearance of new urban elements, it can be observed that many spaces for commuting and many urban traditional environments took important social-cultural functions. Under these circumstances, this research used the descriptive analytical method to focus on evaluating the environments of persistent traditional social business centres in order to achieve persistence in modern social business centres through evaluating and studying the historical background of business centres, urban services and traditional elements that form them.
\end{abstract}

Keywords: Urban public space, Traditional and modern elements, Social sustainability, Business centres, Bazaar

\section{INTRODUCTION}

Public spaces have always been important parts of cities, having much to do with basic routines in a city's life (Cybriwsky, 1999). They are spatially and mentally important parts of cities and play numerous roles in cities and the inhabitants' lives (Nouria, Rafieian and Ghasemi, 2019). Public spaces are dealt with all parts of the built and natural environment that is openly and freely accessible to and useable by all (Neal, 2010; Carmona, Magalhães and Hammond, 2008; Madanipour, 2003; Nissen, 2008; Parkinson, 2009), including those predominantly used for residential, commercial or community/civic purposes (Carmona, Magalhães and Hammond, 2008) and intended for social interaction, relaxation or building passages (Cybriwsky, 1999).

From the past, bazaars have been one of the most vital and important public places due to their various economic and social roles. In addition to an impact on general urban structure and formation of neighbourhoods, they are known as one of the important symbols or valuable and identifiable public architecture. They have been always considered as one of the most important fields of common interactions in civil life. Nowadays, considering the recent transformations and technological progress, online shopping and business, construction of small and big business centres as well as new and wide streets in cities, it can be said that a

School of Architecture and Urban Development, Iran University of Science and Technology, Tehran, IRAN *Corresponding author: ki_ghasemi@mail.iust.ac.ir 
part of the businesses in traditional bazaars has moved to online bazaars, streets and business centres. This, in turn, led the traditional bazaars to gradually lose their status as centres of dynamic economy in many cities and turn into places that are important more due to their cultural and historical aspects. In fact, bazaars no longer can continue their past functions in cities and this leads them to lose their relations with other urban elements and people's social life. This loss of relation that, in itself, is the end of bazaars' lives will eventually lead to gradual some bazaars' death. And places called "passages" have replaced for these elements that, due to business problems, have not been able to be effective in gathering local residents. Therefore, it is befitting to take variables that will increase the level of social wealth in these centres into consideration in designing and planning new business centres (Ghasemi, Hamzenejad and Meshkini, 2019).

Many studies have been conducted in different fields with different approaches, such as architectural, social, geographical and economic, on bazaars, especially on traditional bazaars. Some studies focusing on defining and evaluating the Iranian bazaars, such as the bazaar in Iranian cities from the collection of cities in Iran (Kiani, 1985), Iranian bazaars (Sultanzadeh, 2014), Grand Bazaar of Isfahan (Shafaghi, 2006; Khalili and Fallah, 2018), the historical district of Rasht Great Bazaar (Pourzakarya and Bahramjerdi, 2019), bazaar morphology (Rajabi, 2006), developments in Islamic Iranian bazaars (Saraei, 2010), the role of social capital in the economic situation of traditional bazaars in Iran (PourJafar and PourJafar, 2011); as well as the studies on modern bazaars and commercial complexes can be mentioned as references for planning and designing the shopping centres (Taghvaei and Baygloo, 2008) and commercial complexes (Talebian, Atashi and Nabizadeh, 2013).

This research tries to provide an environment, appropriate for economic and social needs in modern business environment, by relying on persistent social patterns of Iranian traditional business environments with the help of previous sources and researches, through exploratory method.

\section{LITERATURE REVIEW}

The word "bazaar" is an Old Persian word that is now an integral part of Iranian culture (Kermani and Luiten, 2009). According to available information in historical sources, since the beginning of the first century $\mathrm{AH}$, in many new cities and almost all the old cities, permanent bazaars have existed with pre-constructed spaces. Since Seljuk era bazaars have grown and blossomed in urban areas and in Safavid era, due to high level of security, the development of relations and business exchange expansions had peaked (Sultanzadeh, 2014).

From an economical perspective, the term "bazaar" refers to the places in which supply and demand meet each other and end up with equilibrium, in a direct or indirect way (Biglari, 1956). It is a place for trade, buying and selling goods, or is concourse of buyers and sellers (Department of Housing and Urban Development, 2019). However, the concept of bazaar in many Islamic countries, especially Iran, comprises more extensive meanings rather than trading. This idea is mainly inspired by the existence of numerous mosques, schools, hussainias, ${ }^{1}$ tekyehs, ${ }^{2}$ saqqakhanas ${ }^{3}$ and various religious centres in Iranian bazaars. In essence, Iranian bazaars have always been considered as the socio-economic and cultural centres of a city, concentrating all public activities. 
Most of the activities and commutes throughout the city took place in bazaars. Bazaars were the most important communicational channels between citizens, where in addition to exchanging goods and money, the biggest amount of information and news were transferred, or given to people by the government. Another social function of bazaars was the public welcoming of important persons and dignified or royal guests. Guests after entering the city would pass through bazaars' main lanes and would be welcomed by people. During national and religious celebrations, bazaars were the most important places and were decorated to welcome these celebrations. In addition to these, sports competitions, such as wrestling, championship and zourkhaneh (the place to do traditional Iranian sports) rituals, took place in many bazaars. Another important social function of the bazaars was mourning rituals in Muharram (the first month of Islamic calendar). Usually each business held its own rituals and often competed against each other in having held the best rituals. Mourning rituals were also held for other occasions, such as the passing of great religious missionaries and other great persons (Sultanzadeh, 2014). Therefore, bazaar was the most important element, both in political-economic and in social-cultural and in economic-religious areas and the results of its needs and goals formed the image of the city.

\section{TRADITIONAL IRANIAN BAZAARS}

Regarding a general definition of an Islamic city, have been the main focus studies by many geologists, orientalists and especially Islamic studies of the 20th century (Abu-Lughod, 1987; Alsayyad, 1991; Hakim, 1986; Raymond, 1994; 2005; Brown, 1973; Antoniou, 1981; Kostof, 1991; Bonine, 1979; O'Meara, 2007; Kheirabadi, 1991; Lapidus, 1967; 1969; Sauvaget, 1941).

Some of them considered bazaars a fundamental and core part of an Islamic city (Birshak, 1971), but to some others, it was mosques and bazaars (Von Grunebaum, 1961). Another group, according to the ancient and geographical texts, considered city to be divided into three main parts: citadel, congregational mosque and the bazaar (Ashraf, 1978), and finally, some considered mosques, bazaars, government citadel and the core of residential neighbourhoods, walls and bulwarks, and gates to be important elements in the city's construction (Alsayyad, 1991; Hourani, 1970; Meshkini and Ghasemi, 2018).

However, the unity of congregational mosque and bazaars, and their importance is visible in fundamental structure of the Islamic cities. The fact, that socioeconomic and to some extend religious and political, life and function of these cities will persist, is absolute. Some people still consider bazaars to be the centre of all urban activities. In Islamic cities, bazaars are physically dependent on congregational mosques and their functions are close to theirs. Due to the higher priority of religious responsibilities, congregational mosques are built in appropriate places in the centre of the city and bazaars as people's livelihood centre and union activities, are usually built next to congregational mosques (as shown in Figure 1).

Although bazaars, at first, were built for economic reasons, but their physical features and architecture have turned them into a world of activities, social interactions and urban events (Rezaei and Oskovei, 2010). Iranian bazaars are under the influence of Islamic beliefs, worshipping ceremonies, local and cultural traditions, geographical features, economic functions, government's constitutions and people's social behaviours. Therefore, each one of these instances create 
different images that lead to diversity in bazaars environments and show the power of conformability and significance of these environments (Rajabi and Sefahan, 2009). Also, since bazaars have been fundamental and were the centres for urban activities, they were considered as city centres from the economic, social, cultural and political points of view. Furthermore, due to their increased defining roles in cities' destiny, bazaars' centrality, as much as their sociality, in defining citizens' life styles expanded over time.

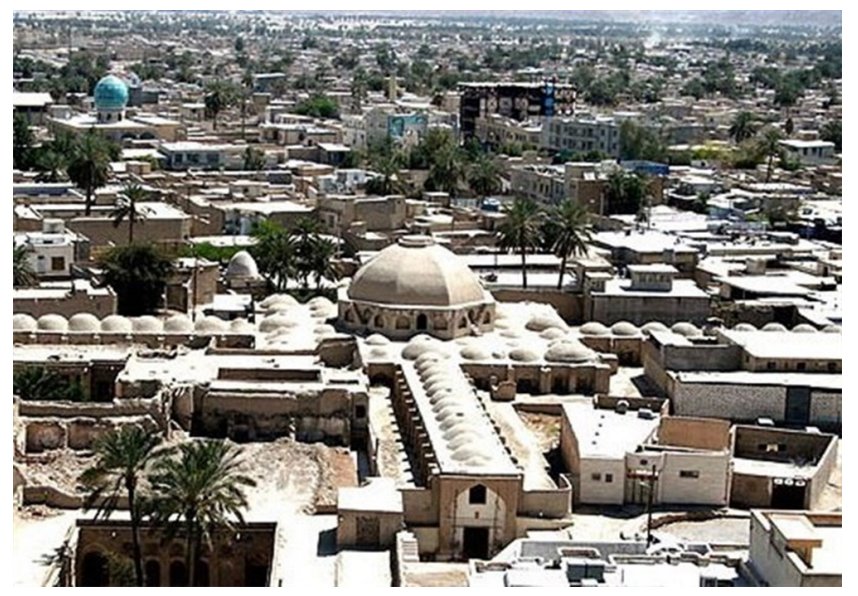

Figure 1. Aerial Photo of the Qaisariya Bazaar in Lar in Fars Province

Iranian bazaars have consisted of elements such as structural identities, each of which, as a semantic element with visual diversity as well as the environment, have led to its sustainability throughout the centuries (as shown in Table 1). These elements include:

1. Rasteh (a lane with covered roof usually with shops): Bazaars as mercantile and service complexes were divided into rows of shops called rasteh. Bazaars often are linear and constructed alongside the most important urban roads. Thus, the most important and fundamental element of bazaars, is their main rasteh. Along the main rasteh different unions are located, in a way that each union was located in a part of the main rasteh. In some greater cities, there were two or more main parallel or transverse rasteh. In medium and big cities, in addition to the main rasteh, there were some adjunct rasteh parallel or vertical to the main rasteh, which were the results of bazaars expanding to adjunct alleys (Sultanzadeh, 2014).

2. Charsoo (crossroads): The transverse section of the two main rasteh. In some historical eras, deriving from the Arabic word, sogh (market) was replaced with charsogh.

3. Maidan (square): Next to or along some of the important bazaars in great cities, there is an urban square or an area, because market was the most important road in the city and in most cases, connected to an urban square (Sultanzadeh, 2014). 
4. Hojreh or dukkan (small shop): Shops were the simplest and smallest elements in the market's environment (as shown in Figure 2). In fact, the fundamental element of the market's environment was the shop, where is the epitome of the social aspect of the market (Raymond, 2005).

5. Dalan (hall, corridor): Dalan is some sort of connector, which often in architectural spaces is linear and plays the role of connector between outer and inner space or only the inner space of the building. And on either side of it, there are usually shops (Sultanzadeh, 2014).

6. Caravanserai: A caravanserai is a place for residence or embarkation and disembarkation for businessmen and international businessmen. It has existed since 2,500 years ago in Iran, in cities and in bazaars and outside of cities on the way of businessmen's and travellers' routes and played the role of hotels and motels; it had the space to keep goods and baggage. Caravanserai is subjective spaces and has a central courtyard, with shops that would be built in one or two floors, around the four sides of the courtyard (Pirnia, 1969).

7. Tim and timche (mini caravanserai): The tim consisted of a courtyard with open space in the middle of it and numerous shops around the open space. The courtyard was used for disembarkation and the whole space was allocated to supplying particular goods and items. The difference between tim and timche is that in timche, only one type of business takes place while in tim, many types of business can take place (Rajabi, 2006).

8. Qeysarrieh: The places, which in their architectural features, look like an adjunct rasteh, dalan or timche or in few instances, like caravanserai, but their function, was often supplying invaluable or luxurious items, especially expensive clothes. Therefore, qeysarriyeh's spaces had one or more entries that were closed during night time (Pirnia, 1969).

9. Jelokhan (mini square): Jelokhan is an urban space, that consists of a connector space in the form of a small square, which from four or three sides is surrounded and has a constructed space. It used as an entry space, lobby or gathering area (Sultanzadeh, 2014).

10. Sacred places, including mosques, tekyeh or hussainia, saqqakhana and seminary schools.

11. Public bathhouses.

12. Zourkhaneh.

13. Teahouses, coffeehouse, traditional restaurants.

14. Doors and gates (to increase security in different areas) (Rajabi, 2006). 
Table 1. Social Sustainability of Iranian Bazaar Based on Five Principles of Iranian Architecture

\begin{tabular}{lll}
\hline $\begin{array}{l}\text { Principles of Iranian } \\
\text { Architecture }\end{array}$ & Concept & Exemplified in the Iranian Bazaar \\
\hline $\begin{array}{l}\text { Human scale } \\
\text { (mardumvârî) }\end{array}$ & $\begin{array}{l}\text { Observing the human } \\
\text { scale in a desirable and } \\
\text { popular way }\end{array}$ & $\begin{array}{l}\text { The shape and appearance of the } \\
\text { bazaar has been spatially organised } \\
\text { in accordance with the beneficial } \\
\text { human needs and conditions; this } \\
\text { spatial organisation includes the role } \\
\text { of production and supply of goods } \\
\text { alongside the religious, social, cultural } \\
\text { derived from the spirit of Islamic } \\
\text { thought that acts as a living organism } \\
\text { and has become an independent } \\
\text { entity in stages such as shaping, } \\
\text { evolution, and transformation. }\end{array}$ \\
\hline
\end{tabular}

Self-sufficiency Maximise the use of (khudbasandagi) existing and available facilities without violating the resources and future needs
1. The traditional bazaar is precisely consistent with self-sufficiency and in a variety of locations, with its full complement of materials on the site and particularly indigenous, it represents a complete form of traditional architecture that is consistent with its environment.

2. The lack of repetition and imitation of patterns, styles, and imported foreign functions in the Iranian bazaar, the consistency of the features of space with the human characteristics of humankind will satisfy many of the social needs in the bazaar.

3. The traditional bazaar stands as the authority symbol ancient traditions against the particular urban spatial reflections arising from the growth of modern thought, such as the western and modern streets and squares of the high-rise buildings.

\begin{tabular}{ll}
\hline Inward-looking & Maintaining the inner \\
(darûngerāyī) & spaces from the \\
& external conditions \\
and organising interior \\
architectural spaces
\end{tabular}

1. In the buildings that exist in the traditional bazaars such as saras, timches, mosques, tekyehs, religious schools, husseiniyahs and caravansaries, the most crucial part of the open space is an interior part, which draws the human movement inward and creates a sense of fixation, security and proximity in the individual or buyer. 
Table 1. Continued

\begin{tabular}{|c|c|c|}
\hline $\begin{array}{l}\text { Principles of Iranian } \\
\text { Architecture }\end{array}$ & Concept & Exemplified in the Iranian Bazaar \\
\hline & & $\begin{array}{l}\text { 2. Inside the bazaar, there were } \\
\text { central spaces such as the } \\
\text { chaharsouq and timches, which } \\
\text { plays the role of an open interior } \\
\text { or a courtyard and induces the } \\
\text { acceptor soul of Iranian life, and } \\
\text { also prevents the crowding and } \\
\text { fatigue caused by the bustle of the } \\
\text { commercial space. }\end{array}$ \\
\hline & & $\begin{array}{l}\text { 3. There are hierarchical spaces of } \\
\text { pause and attention to privacy in } \\
\text { the Iranian bazaar. }\end{array}$ \\
\hline $\begin{array}{l}\text { Avoiding non- } \\
\text { essentials (parhīz } \\
\text { az bihudagi) }\end{array}$ & $\begin{array}{l}\text { Architectural targeting } \\
\text { and avoid doing in non- } \\
\text { essentials works }\end{array}$ & $\begin{array}{l}\text { The Iranian bazaar is an example of } \\
\text { the use of the space with the least } \\
\text { distraction and the maximum use, and } \\
\text { even the decorations are suitable and } \\
\text { applicable, by avoiding the futility of } \\
\text { space and avoiding unnecessary } \\
\text { embellishments. }\end{array}$ \\
\hline $\begin{array}{l}\text { Structural rigidity } \\
\text { (niyārish) and } \\
\text { homogeneous } \\
\text { proportion } \\
\text { (paymūn) }\end{array}$ & $\begin{array}{l}\text { Resistance and stability } \\
\text { of the building and the } \\
\text { determination of the } \\
\text { analogy between the } \\
\text { components of the } \\
\text { building }\end{array}$ & $\begin{array}{l}\text { Structural rigidity and paymün give } \\
\text { the symmetry and durability to these } \\
\text { monolithic and interconnected } \\
\text { bazaars and so that it is impossible to } \\
\text { dissociate them and create a unified } \\
\text { and permanent form that this semantic } \\
\text { unity is itself a factor of stability and } \\
\text { indelibility of this element. }\end{array}$ \\
\hline
\end{tabular}

Source: Pirnia and Afshar (1991)

\section{MODERN IRANIAN BAZAARS}

"Passage" in English means a place to pass through; a space that connects two buildings to each other. In French, routes, on either side of which there are business environments, are also called "passages" (Sultanzadeh, 2014). At the end of the 18th and the beginning of the 19th centuries, in most great cities, passages were gradually constructed (Taghvaei and Baygloo, 2008) and in many countries, progress in industry, mass production and consumerism led to big bazaars constructed to meet people's needs in shorter time (Zadeh, 2009). In Iran, big passages and chain bazaars started to appear during the Pahlavi era (Rajabi, 2006). In the 20th century, with daily increase in urban population and vehicles, and suburban population, construction and business companies turned to constructing new buildings and shopping centres, in order to provide comfort for people and customers for shopping and receive better profits. 
(a)

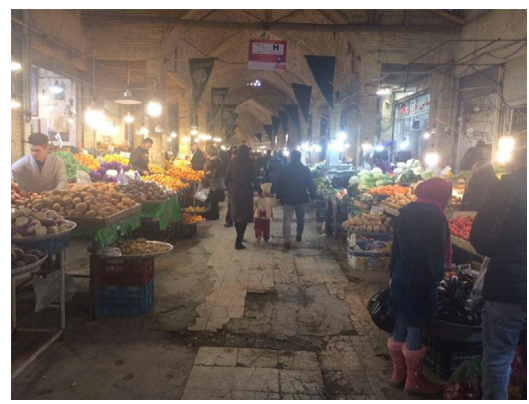

(c)

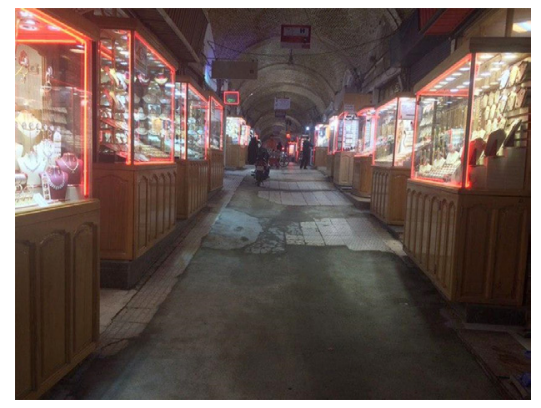

(e)

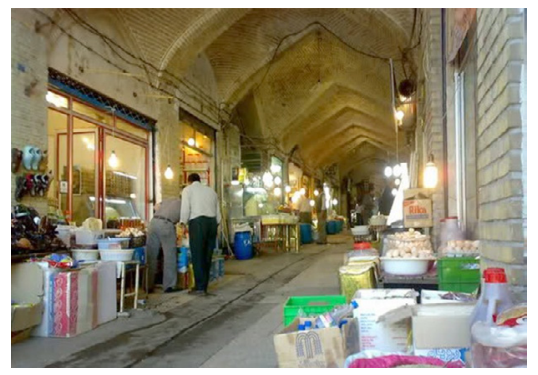

(g)

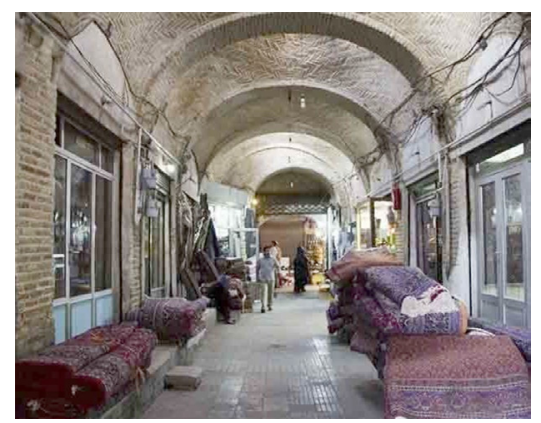

(b)

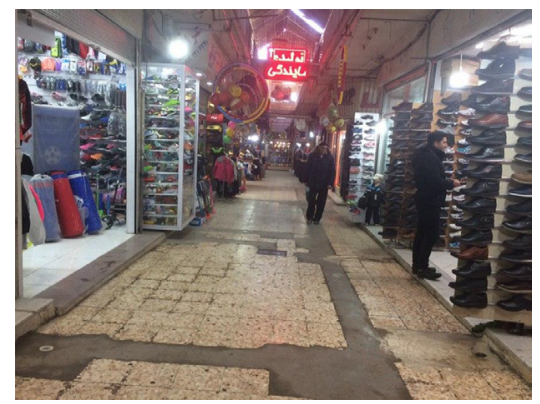

(d)

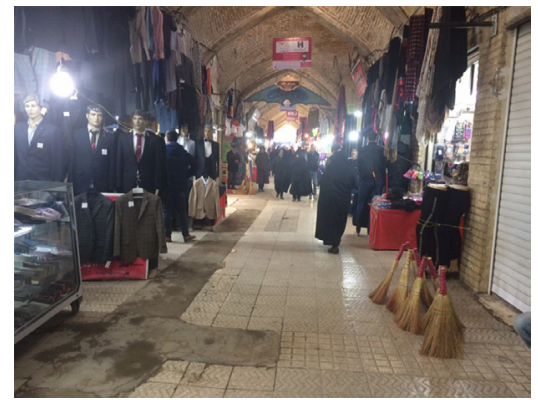

(f)

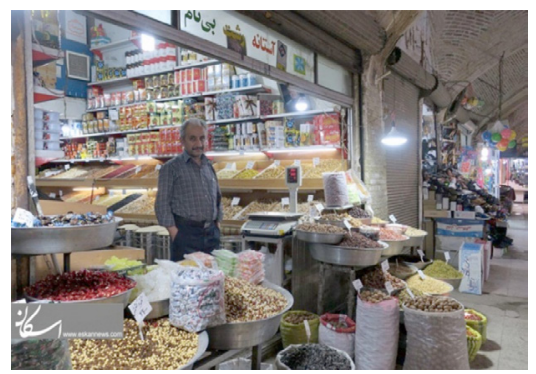

(h)

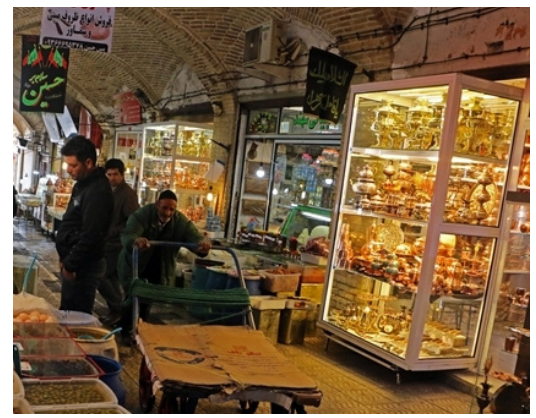

Figure 2. Distribution of Different Guilds in a Traditional Iranian Bazaar: (a) Fruits, (b) Shoes, (c) Jewellery, (d) Textiles, (e) Dairies, (f) Groceries, (g) Carpets and (h) Crafts 
The formation of passages along streets and urban caravanserai along market lanes can be partially considered alike since passages were usually built in those streets and areas of the city, where on the one hand, economy had boomed and on the other hand, expanding shops on the edge of the sidewalks and streets would not be easy. Initial passages, looked a lot like urban caravanserais, but gradually they turned into new forms. Some of which were allocated to offices. Buildings that in some fields look like passages are practically different from the initial passages (Sultanzadeh, 2014). As a result, dominant forms of business spaces in Tehran today are in the form of streets and passages that function competitively (as shown in Figure 3).
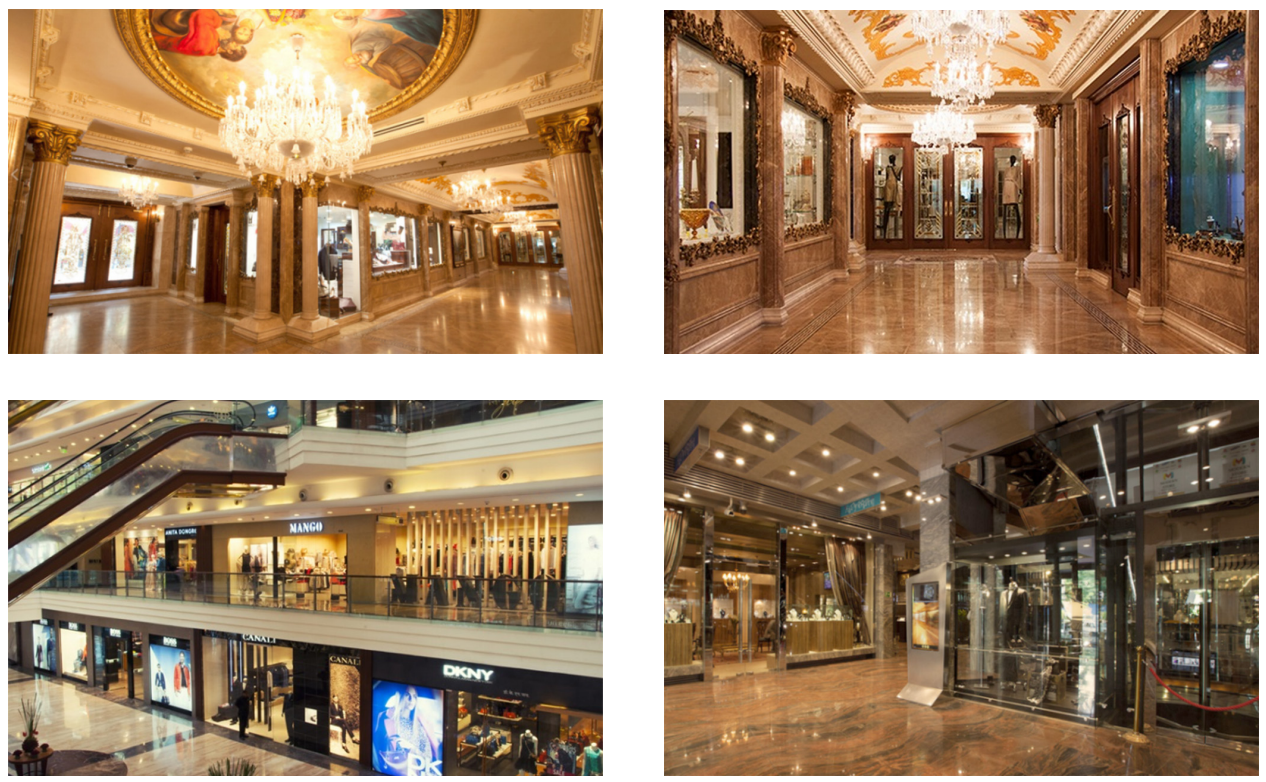

Figure 3. An example of Modern Bazaar in Iran

Todays, in addition to traditional bazaars and passages and big chain bazaars, there are different shopping centres, constructed in recent years and some are in the planning and construction phase. In the past few years, the merely business function of bazaars has changed into business-entertainment and creating places for leisure time and entertainment (as shown in Figure 4) in such environments in modern forms are now common in Iran (Ahour et al., 2013). 
(a)

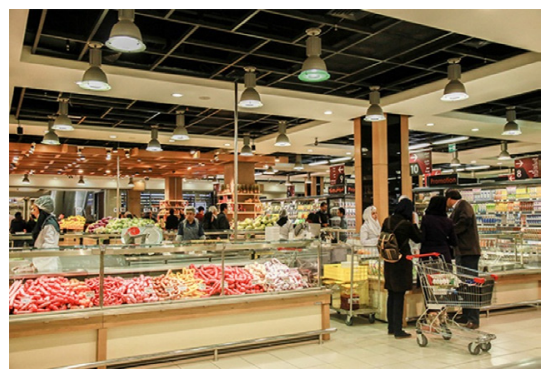

(c)

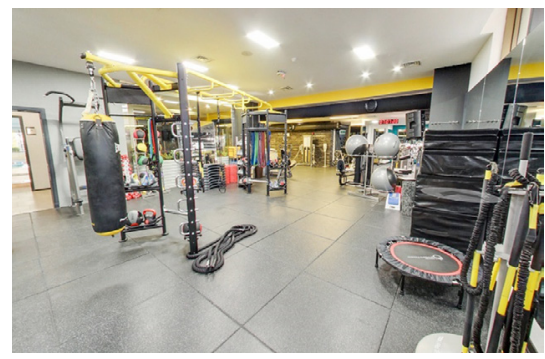

(e)

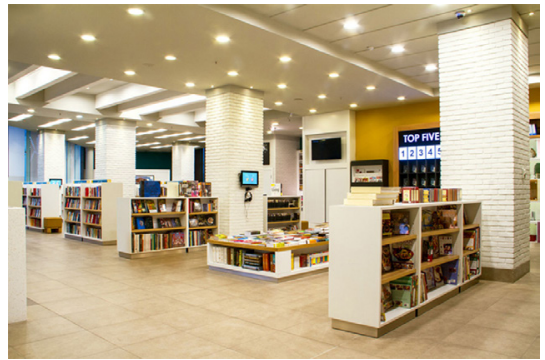

(b)

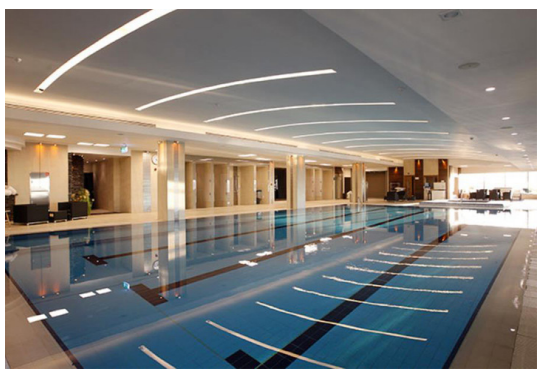

(d)

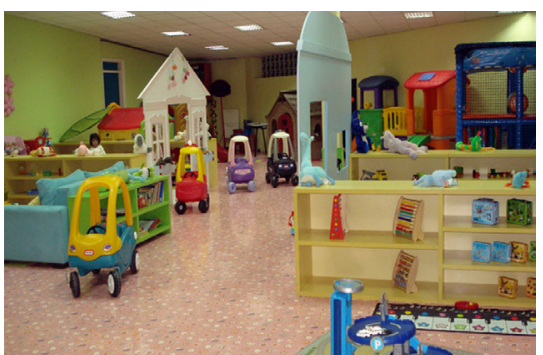

(f)

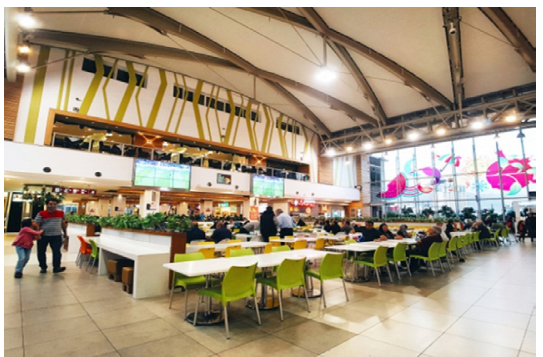

Figure 4.

Distribution of Different Services in a Modern Iranian Bazaar: (a) Hypermarket, (b) Swimming Pool, (c) Gym, (d) Baby House, (e) Library and (f) Cafés and Restaurants

The most important elements of the new business centres are as follows:

1. Lobby or an entrance saloon that plays a defining and glorious role in the whole collection and does not have a social role and is at best as a waiting space.

2. Large and small saloons with glamorous exhibition showcase, with great differences from the traditional market and attract a large number of audiences.

3. Corridors that play the motivational role of traditional market by eliminating the qualities of natural light and increasing the excitement of lighting.

4. A large space that is usually visible from all parts of the shopping complex and has a coffee shop and a dining room. 
5. Floor restaurants that are usually located on the highest floors with beautiful views and traces and high attractiveness of entertainment and nutrition centres.

6. Computer game centres and gyms for children and the youth, which are located on the lower or upper floors.

7. Cinemas: In some commercial centres, some specialised cultural centres have been added that invite the educated customers. Nevertheless, these audiences do not interact and participate only in an independent friendly or family nucleus using a cultural package.

\section{RESULTS}

Traditional bazaars had a wider range of social functions, as compared to the modern bazaars. Traditional bazaars' functions in the past can be divided into four categories: economic, political, social-cultural and religious. Modern and traditional bazaars only share the economic function and other functions in modern bazaars are either completely gone or not as important. The leisure-entertainment function is only seen in the modern bazaars and traditional bazaars do not play this function. These functions (as shown in Table 2) will be discussed further.

Table 2. The Functions of Traditional Bazaars Compared to Modern Bazaars

\begin{tabular}{|c|c|c|}
\hline \multicolumn{3}{|c|}{ Traditional Bazaar } \\
\hline \multirow[t]{6}{*}{ Functions } & Economic & $\begin{array}{l}\text { 1. Trading place. } \\
\text { 2. Response to the economic needs. }\end{array}$ \\
\hline & Political & $\begin{array}{l}\text { 1. A place for riots, strikes and so on. } \\
\text { 2. A place for all kinds of information and awareness } \\
\text { of news and political debate. }\end{array}$ \\
\hline & Religious & $\begin{array}{l}\text { Locating the bazaar next to a religious monument or } \\
\text { build a religious place such as mosque and various } \\
\text { religious centres in bazaars. }\end{array}$ \\
\hline & Social-cultural & $\begin{array}{l}\text { 1. A place to meet, transfer customs, traditions, } \\
\text { ideas, news and manners of social behaviour }\end{array}$ \\
\hline & & $\begin{array}{l}\text { 2. A place for mourning, national and religious } \\
\text { celebrations and so on. }\end{array}$ \\
\hline & $\begin{array}{l}\text { Recreational/ } \\
\text { leisure }\end{array}$ & This function in traditional bazaars was less important. \\
\hline \multicolumn{3}{|c|}{ Modern Bazaar } \\
\hline \multirow[t]{3}{*}{ Functions } & Economic & Response to the economic needs. \\
\hline & $\begin{array}{l}\text { Recreational/ } \\
\text { leisure }\end{array}$ & $\begin{array}{l}\text { 1. Build places for children's play and } \\
\text { entertainment for other people. }\end{array}$ \\
\hline & & $\begin{array}{l}\text { 2. Build places such as coffee shops and } \\
\text { restaurants for leisure and relaxation in shopping } \\
\text { malls. }\end{array}$ \\
\hline
\end{tabular}




\section{Economic Function}

This function is known as the main function of bazaar, as an economic organisation since bazaars have always been the main business centre in the city and was places for buying and exchanging life's necessary and unnecessary goods and items and people in the past would answer most of their livelihood needs in bazaars. This function can be considered the mutual function, in both traditional and modern bazaars.

\section{Social-Cultural Function}

This function has two aspects, conceptual and visual. The visual aspect is about the market's structural architecture that, which represents a rich culture in the past, through which, the image of the past society and culture is formed, On the other hand the structural type of market that, includes different parts, such as rasteh (bazaar street), to which all adjunct lanes vertically connect and hallways that, themselves look like caravanserais or shopping centres and are connected to the main and adjunct lanes and other parts of the market, such as hammam (public bathhouse), zourkhaneh, qahuwakhana (coffeehouse), madrasa (school) and masjid (mosques), which all are the backgrounds of the conceptual aspect of this function and represent some type of special communicational space between people and people working in bazaars and generally between many circles of people, who would interact with each other in these places every day and would help this unity development among the people in the society. In fact, this function is the same as what habermas interprets as public field i.e. in the 19th century in Europe, different people from intellectuals to ordinary people gathered around in public places, such as cafés and canteens, to discuss and talk about important events of the day and have reasonable talks for the good or bad of the society (Outhwaite, 2009).

\section{Political Function}

Government has always played an important role in bazaars, in different ways; whether being in harmony with religion or not bazaars, in many cases, were constructed and expanded next to government citadels and alongside its entry gate. Bazaars and their services, throughout history, have always had such powers that have always been of importance to rulers and governments of the time. Therefore, mostly in all of the old cities of Iran, government and political centres were constructed near bazaars (Pourahmad, 1997).

\section{Religious Function}

Since its formation, market has had so strong relations with religion that among the most important places in market were mosques including Shah (Imam) Mosque and seminary schools and places, where religious rituals, such as celebrations and mourning, were held could be found in markets. Moreover the businessmen had strong relations with the men of the cloth; the businessmen, who wanted to benefit more from their economic activities, needed to have both religious and social high status. First, they had to have halal income and to this end, they had 
to pay khums (the one-fifth tax) and zakat and therefore, ulama (the men of the cloth) would confirm that their property is halal. Second, by doing social-religious significant activities, such as constructing mosques and schools and going on a pilgrimage to Mecca, they would introduce themselves as devout persons. On the other hand, marriage between the family of businessmen and clergies would strengthen these relations, all these would result in, in a two-way relation between reputable businessmen and legitimacy of clergies, boom of businesses and ulama could answer their financial needs, through businessmen (Kamali, 2018).

\section{The Recreation-Leisure Function}

This function is specific to modern bazaars and business complexes. In fact, in traditional bazaars this role was not as important. In the architecture of the modern complexes, building places for children to play and places such as cafés and restaurants show that bazaars, apart from economic needs, partially meet the customers' leisure needs, too. This would help the customers to relax and get away from the pressure of work during the day and have hours with their families, filled with pleasure and happiness. On the other hand, nowadays, the concept of shopping, in itself, is of leisure nature and helps to pass free time because in the past, most of the people would go to bazaars to meet their need but today many people buy more than what they need.

However, modern bazaars, nowadays, as new public arenas have diminished the prominent role of the traditional bazaar and caused new relationships along with a new lifestyle. The role of the traditional bazaar in identifying cities has diminished. If, in the near past, every city was known for its traditional bazaar and the modern bazaar architecture gave a distinct identity to the city, now dozens of shopping malls with modern architecture have symbolically replaced by traditional and local architecture of traditional bazaars. On the other hand, the traditional relations that dominated in the bazaar and spread throughout the city have changed. Changing most of its activities, the bazaar performs the first space transfer from a specific location to a location that changes over time. As a result of these developments, the bazaars of the Iranian cities had different destinies:

1. Some of these bazaars such as the Semnan Bazaar were worn out due to isolation and lack of desired access and were gradually moved to the sidewalks. Erosion of empty spaces destroyed them.

2. Some of them such as the Ardabil Bazaar were torn by the streets and the remaining parts changed their activities depending on the new situation in the city.

3. Some of the bazaars such as the Isfahan Bazaar have retained their original identity due to the region's richness in the production of domestic industries and have been kept from the influence of new situation to some extent.

Todays, like old neighbourhoods, alleys and urban spaces, markets cannot meet today's consumerist and fashion-oriented needs. Moreover, extensive physical changes such as building parks, restaurants, stadiums, museums, cultural centres, etc. have also occurred in shopping malls and the changes in the body of contemporary shopping malls can be interpreted in the change in lifestyle and social relations. 
In fact fundamental changes, in the new era, took place in the correlation of values and coherent lifestyle, which led to the independence and entertainment of shopping and turned its location from the mediating the important religious and political centre to a recreational centre and a factor to concern fashion and satisfying the need to be up-to-date and global. This is, on the one hand, the result of development in social welfare and, on the other hand, an incompetency in social solidarity.

\section{CONCLUSION}

Economic and social transformations in today's Iranian urban lives have been effective in the general situation of bazaars. These transformations that resulted from the population growth, street expansion and new street shops have disestablished traditional market as the only business centre in cities. Nevertheless, they have never been an obstacle against the market growth. During the past two decades, physical expansion of the cities in Iran, on the one hand and social and political growth in cities, accompanied with new ideas in urban engineering and urbanisation, on the other hand, led to the formation of new roles and functions in all urban, local and regional divisions and some special parts of the city to be specified to business functions. These functions were formed through the construction of passages and big modern business complexes to gradually disestablish traditional bazaars as the main business centres providing numerous luxurious goods to meet the people's needs. Many experts introduce different reasons for traditional bazaars' relative falter; the main reason is known to be the change in people's lifestyle in cities, the expansion of business chain complexes and online shopping.

Analysing Iranian bazaars, as public environments, where most of the Iranian's social events took place, reveals most of undeniable visual, conceptual and functional features. These social caused a special discipline in bazaars to be performed, which changed the people's behaviour towards bazaars as only a business environment and turned bazaars into great and vast environments for social activities. According to the new perspective towards bazaar, bazaar and viewers (people, businessmen) form a united entity and have a social life alongside each other. Apart from the fact that core and main parts of bazaars play an important role in the formation of this social life, the physical appearance of the market inevitably conforms to the Iranian social lifestyle and activities.

Since bazaars in Iran are known as one the most important urban factors in social interactions and one of the most important and fundamental places to gather together and have fun, increasing social interactions in modern business centre as new and modern generation of bazaars is one the most important problems and current social topics, which needs further discussion. Thus, five important principles in traditional Iranian architecture, including human scale architecture, self-sufficiency, avoiding non-essentials, inward-looking and structural rigidity are discussed as follows:

1. Physical patterns of market in the past and the study of feasibility of patterning by using these physical patterns in modern business centres: Though traditional bazaars had different lanes and areas for each union, the businessmen were encouraged to coexist and have unity rather than a false competition in business. 
2. The harmony in supply and demand undermined the possibilities of false competitions.

3. The higher religious organisations in market were involved in encouraging unity among the businessmen and on special religious or political occasions directed people in one carnival.

4. To encourage ethics, a set of rules was defined by the veterans, rather than forums and syndicates, of each field for the same field and everyone followed the rules; in case of a complaint, the dispute was finished by a mediator.

5. This controlled friendly and public environment led to relative security and hindered any abuse or robbery, whether by friends or strangers. This would happen through inward-looking physic and cohesive system of arranging lanes and their combination with religious and educational, and even residential centres. Today, the big partition between life and business centres and the separation of these centres from other needs has created an unhealthy competition among businessmen, which has replaced that friendly environment with tension.

It seems that breaking passages and big bazaars into smaller regional bazaars, accompanied with the booming of the cyberspace alongside the real life, not only reduces the harmful transportations in the city but also the decreased direct interaction of people, caused by the cyberspace. Therefore, it can provide opportunities for qualitative and low-risk interactions in near residential areas with collectivity of cultural, entertainment and religious behaviours.

\section{ACKNOWLEDGEMENTS}

This study was funded by the Iran National Science Foundation (INSF), Grant Number: 97018482.

\section{NOTES}

1. Hussainia is a congregation hall for Shia commemoration ceremonies, especially those associated with the Remembrance of Muharram (EduardoCampo, 2009).

2. Tekyeh is a place where Shiite gathers for mourning in Muharram (EduardoCampo, 2009).

3. Saqqakhana is a small space in public areas built by Iranians to provide water for passengers (Ghasemi, Hamzenejad and Meshkini, 2019). 


\section{REFERENCES}

Abu-Lughod, J.L. (1987). The Islamic city: Historic myth, Islamic essence and contemporary relevance. International Journal of Middle East Studies, 19(2): $155-176$.

Ahour, I., Jajromi, K., Nazariyan, A. and Moshiri, R. (2013). From bazaar to megamall. Environmental Based Territorial Planning, 6(20): 145-176.

Alsayyad, N. (1991). Cities and Caliphs, on the Genesis of Arab Muslim Urbanism. New York: Greenwood Pres.

Antoniou, J. (1981). Islamic Cities and Conservation. Paris: UNESCO Press.

Ashraf, A. (1978). Historical features of urbanization in Iran-Islamic period. Social Science Letter, 1-43.

Biglari, E. (1956). The Iranian bazaars [in Persian]. Journal of Architecture and Art, 162(1): 47-56.

Birshak, S. (1971). Recognizing and Studying the Traditional Bazaar of Iran. Tehran: Faculty of Arts, University of Tehran.

Bonine, M.E. (1979). The morphogenesis of Iranian cities. Annals of the Association of American Geographers, 69(2): 208-224. https://doi.org/ 10.1111/j.1467-8306.1979.tb01252.x.

Brown, L. (1973). From Madina to Metropolis: Heritage and Change in the Near Eastern City. Princeton, NJ: Darwin Press.

Carmona, M., Magalhães, C. and Hammond, L. (2008). Public Space: The Management Dimension. London/New York: Routledge.

Cybriwsky, R. (1999). Changing patterns of urban public space: Observations and assessments from the Tokyo and New York metropolitan areas. Cities, 16(4): 223-231. https://doi.org/10.1016/S0264-2751(99)00021-9.

Department of Housing and Urban Development (2019). Documentation of Experience in Iranian Market, Architectural Assistant/Office Architecture and Urban Design [in Persian]. Tehran: Jahad Daneshgahi of Tehran Publications.

Eduardo-Campo, J. (2009). Encyclopedia of Islam. New York: Infobase Publishing.

Ghasemi, K., Hamzenejad, M. and Meshkini, A. (2019). The livability of Iranian Islamic cities considering the nature of traditional land uses in the city and the rules of their settlement. Habitat International, 90: 102006. https://doi.org/10.1016/j. habitatint.2019.102006.

Hakim, B. (1986). Arabic-Islamic Cities: Building and Planning Principles. London: KPI. Hourani, A. (1970). The Islamic City in the Light of Recent Research. Oxford: Cassirer. Kamali, M. (2018). Revolutionary Iran: Civil Society and State in the Modernization Process. London/New York: Routledge.

Kheirabadi, M. (1991). Iranian Cities: Formation and Development. Austin, TX: University of Texas Press.

Kermani, A.A. and Luiten, E. (2009). The impact of modernization on traditional Iranian cities. In Environmental Science and Sustainability. Baltimore: WSEAS Press, 79-84.

Khalili, A. and Fallah, S.N. (2018). Role of social indicators on vitality parameter to enhance the quality of women's communal life within an urban public space (Case: Isfahan's traditional bazaar, Iran). Frontiers of Architectural Research, 7(3): 440-454. https://doi.org/10.1016/j.foar.2018.06.001.

Kiani, Y. (1985). The Bazaar in Iranian Cities from the Collection of Cities in Iran. Tehran: Ministry of Culture and Islamic Guidance. 
Kostof, S. (1991). The City Shaped: Urban Patterns and Meanings through History. Boston: Little Brown.

Lapidus, I.M. (1969). Muslim cities and Islamic societies. In I.M. Lapidus (ed.), Middle Eastern Cities: A symposium on Ancient, Islamic and Contemporary Middle Eastern Urbanism. Berkeley: University of California Press.

(1967). Muslim Cities in the Later Middle Ages. Cambridge: Harvard University Press.

Madanipour, A. (2003). Public and Private Spaces of the City. London/New York: Routledge.

Meshkini, A. and Ghasemi, K. (2018). The Most Important Principles of Iranian Islamic's Urban Planning. Chişinău, Republic of Moldova: Lambert Academic Publishing.

Neal, Z. (2010). Seeking common ground: Three perspectives on public space. Urban Design and Planning, 163(2): 59-66. https://doi.org/10.1680/udap .2010 .163 .2 .59 .

Nissen, S. (2008). Urban transformation from public and private space to spaces of hybrid character. Sociologický Časopis/Czech Sociological Review, 44(6): 1129-1149.

Nouria, Z., Rafieian, M. and Ghasemi, K. (2019). Using information and communication technologies to create learning urban public space. (Case study: Central part of Tehran, Iran). Habitat International, 87: 91-98. https://doi.org/10 $.1016 /$ j.habitatint.2019.04.002.

O'Meara, S. (2007). Space and Muslim Urban Life: At the Limits of the Labyrinth of Fez. New York: Routledge.

Outhwaite, W. (2009). Habermas: A Critical Introduction. Cambridge, UK: Polity Press.

Parkinson, J. (2009). Symbolic representation in public space: Capital cities, presence and memory. Journal of Representative Democracy, 45(1): 1-14. https://doi.org/10.1080/00344890802709781.

Pirnia, M. (1969). The Iranian bazaar. Journal of Archaeology and Iranian Art, 55-60.

Pirnia, M. and Afsar, K. (1991). Road and Robat. Tehran: Armin.

Pourahmad, A. (1997). Geography and Function of Kerman Bazaar. Kerman, Iran: Kermanshenasi.

PourJafar, M. and PourJafar, A. (2011). The role of social capital in the economic situation of traditional bazaars in Iran. Urban Management, 27(Supp.): 203221.

Pourzakarya, M. and Bahramjerdi, S.F.N. (2019). Towards developing a cultural and creative quarter: Culture-led regeneration of the historical district of Rasht Great Bazaar, Iran. Land Use Policy, 89: 104218. https://doi.org/10.1016/j. landusepol.2019.104218.

Rajabi, A. (2006). Bazaar Morphology. Tehran: Agah.

Rajabi, A. and Sefahan, A. (2009). Iranian bazaars embody sustainable thoughts. Geography, 11: 113-127.

Raymond, A. (2005). Urban life and Middle Eastern cities: The traditional Arab city. In Y.M. Choveiri (ed.), A Companion to the History of the Middle East. Oxford: Blackwell Publishing Ltd. https://doi.org/10.1002/9780470996423.ch12.

(1994). Islamic city, Arab city: Orientalist myths and recent views. British Journal of Middle Eastern Studies, 21(1): 3-18. https://doi.org/10 $.1080 / 13530199408705589$.

Rezaei, A.M. and Oskovei, F.B. (2010). Traditional bazaar: The crystallization of contemporary urban utopias. Designer, 160-164. 
Saraei, M. H. (2010). Developments in Islamic Iranian bazaars: Case study of Yazd Bazaar. Journal of Studies on Iranian Islamic City, 2(1): 25-37.

Sauvaget, J. (1941). Alep: Essai sur le Df!veloppement d'une Grande Ville Syrienne, des Origins au Milieu du XIXe Siecle. Paris: P. Geuthner.

Shafaghi, S. (2006). Grand Bazaar of Isfahan. Isfahan, Iran: Cultural and Recreational Organization of Isfahan Municipality.

Sultanzadeh, H. (2014). Iranian Bazars. Tehran: Cultural Research Bureau.

Taghvaei, M. and Baygloo, R.S. (2008). Planning and Designing of the Shopping Centres. Isfahan, Iran: Kankash.

Talebian, N., Atashi, M. and Nabizadeh, S. (2013). Commercial Complex. Mashhad, Iran: Kasra.

Von Grunebaum, G.E. (1961). Islam: Essays in the Nature and Growth of a Cultural Tradition. London: Routledge \& Kegan Paul.

Zadeh, A.A. (2009). The evolution of the formation of commercial spaces in the west and east from the viewpoint of architectural history. Abadi, 60-70. 